\title{
PENGEMBANGAN TES MINAT DAN BAKAT DENGAN METODE JARINGAN SYARAF TIRUAN (JST) UNTUK MEMPREDIKSI POTENSI SISWA BIDANG ROBOTIKA
}

\author{
Andik Asmara \\ Universitas Negeri Yogyakarta \\ simp302030@yahoo.co.id \\ Haryanto \\ Universitas Negeri Yogyakarta \\ haryanto.ftuny@gmail.com²
}

\begin{abstract}
Abstrak
Penelitian pengembangan ini bertujuan untuk: (1) mengembangkan model tes minat dan bakat dengan metode jaringan syaraf tiruan; (2) memperoleh hasil uji fungsionalitas tes minat dan bakat yang dikembangkan dengan model Jaringan Syaraf Tiruan (JST); dan (3) memperoleh hasil unjuk kerja dari pengujian tes minat dan bakat dengan model jaringan syaraf tiruan untuk memprediksi potensi siswa bidang robotika. Penelitian ini merupakan penelitian dan pengembangan. Subjek uji coba dibagi menjadi dua, uji coba secara terbatas pada 10 siswa dan uji coba secara luas sebanyak 31 siswa. Hasil dari penelitian pengembangan ini adalah: (1) keberhasilan produk yang dikembangkan dengan beberapa spesifikasi model yaitu; (a) JST dibangun dengan struktur single layer, jawaban tes sebagai masukan dan kesimpulan hasil tes sebagai keluaran; (b) Model pembelajaran JST menggunakan metode perceptron dengan model aktifasi pada JST menggunakan model bipolar (symmetric hard limit); (2) Proses pembelajaran secara terbimbing dengan 10 pola mendapatkan bobot yang dapat membedakan 10 pola dengan tepat, berdasar pengujian secara terbalik. (3) Pengujian secara luas menunjukan produk yang dibangun mampu memprediksi potensi siswa dalam bidang robotika, dengan membedakan 31 pola hasil tes siswa yang berbeda dengan menggunakan bobot yang didapat dari 10 pola pembelajaran.
\end{abstract}

Kata kunci: Tes Minat dan Bakat, Jaringan Syaraf Tiruan, Robotika

\section{DEVELOPING INTEREST AND TALENT TEST USING ARTIFICIAL NEURAL NETWORK (ANN) TO PREDICT STUDENTS' APTITUDE IN ROBOTICS}

\begin{abstract}
This investigation was aimed: (1) to develop the model of interest and talent test using ANN; (2) to obtain the results of functionality examination of interest and talent test which is developed using $A N N$; and (3) to obtain the results of the performance from the examination of interest and talent test which is developed using ANN to predict students' aptitude in robotics. This study was a research and development. Subjects were divided into two trials, limited trial was given to 10 trainee students, and wider trial was tested on the 31 students. From the analysis, it can be concluded that: (1) the success of the products developed had some model specifications as follows; (a) ANN was built with a single-layered structure, the answers to the test was the input and the conclusion of the test was as output. (b) ANN learning model used a neural network perceptron method with activation of the ANN using bipolar model (symmetric hard limit). (2) The learning process was guided by the 10 patterns that could be weighted appropriately to distinguish 10 patterns, based on testing in reverse. (3) Extensive testing showed the developed product was able to predict the aptitude of students in the field of robotics, by distinguishing 31 different student examination result pattern using the weights obtained from the 10 patterns of learning.
\end{abstract}

Key Words: Interest and Talent Tests, Artificial Neural Network, Robotics 


\section{PENDAHULUAN}

Salah satu persoalan pendidikan yang dihadapi Bangsa Indonesia adalah masih tingginya angka putus sekolah. Pusat Data dan Statistik Pendidikan (PDSP, Kemendikbud) 2010 menunjukan bahwa 90.263 siswa SMA/ SMK/MA siswa putus sekolah. Yogyakarta sebagai kota pendidikan juga tidak lepas dari permasalahan terdapatnya siswa putus sekolah. Data yang diperoleh dari basis data Kementrian Pendidikan dan Kebudayaan menunjukan di Yogyakarta pada tahun 2008 sebanyak 2.864, tahun 2009 sebanyak 4.326, tahun 2010 sebanyak 2.208 dan tahun 2011 sebanyak 6.659. Persentase tingkat putus sekolah siswa SMK di Yogyakarta mencapai titik tertinggi sebesar 4\%. Oleh karena itu permasalahan ini perlu dilihat dari beberapa sudut pandang permasalahan yang dihadapi di SMK.

Putus sekolah dapat disebabkan bebarapa faktor, diantaranya faktor ekonomi, pergaulan, kenyamanan disekolah dan minat peserta didik pada bidang keahlian yang di pilihnya. Faktor dominan yang menyebabkan tingginya siswa putus sekolah adalah faktor ekonomi. Tetapi faktor lain seperti pergaulan, kenyamanan dan pilihan minat pada bidang keahlian yang dipilihnya juga memberi sumbangan siswa putus sekolah. Pemerintah melihat permasalahan tersebut dan melakukan tidakan lebih dini dengan menerapkan kebijakan proses peminatan. Secara teoritis seorang siswa yang memiliki minat yang tinggi, akan menimbulkan motivasi belajar yang baik.

Proses peminatan bertujuan untuk menempatkan siswa sesuai bidang keahlian yang tepat, sehingga menimbulkan motivasi dan keyamanan dalam proses pembelajaran. Bidang keahlian yang sesui menjadi bekal kedepan apabila siswa memasuki dunia kerja. Dikutip dari tulisan Samani (1998, p.2) yang merupakan guru besar Univesitas Negeri Surabaya, bahwa sebagai pendidikan yang menyiapkan pesertanya untuk memasuki dunia kerja, maka relevansi pendidikan memegang kunci amat penting. Relevansi harus diartikan sebagai kesesuaian bekal yang dipelajari peserta didik dengan tuntutan dunia kerja yang akan dimasuki setelah lulus, ditinjau dari jenis maupun kualitasnya. Berarti pendidikan kejuruan harus mampu memprediksi jauh ke depan, dari saat program pendidikan dirancang.

Berdasarkan kutipan tersebut, pendidikan/ proses pembelajaran lembaga pendidikan harus memiliki keterkaitan dengan kebutuhan dunia kerja dan kebutuhan peserta didik. Peserta didik memiliki tujuan dan kebutuhan yang ingin di penuhi saat menempuh pendidikan. Kebutuhan dunia kerja dan dalam diri peserta didik harus mampu dipetakan/diprediksi untuk digunakan dalam perancangan program pendidikan. Program pendidikan dapat digolongkan secara luas atau sempit.

SMK sebagai salah satu pendidikan kejuruan tidak jauh dari pendidikan vokasi yang memiliki standar tolok ukur keberhasilan. Keberhasilan suatu pendidikan vokasi menurut Erlin Leigh Parker (2008) diidentifikasi terdapat beberapa faktor, salah satu diantaranya yang penting adalah Recruitment atau penerimaan peserta didik. Apabila penggunaan alat penerimaan peserta didik bagus (one of the best recruiting tools), akan menghasilkan lulusan yang bagus juga (Erlin Leigh Parker, 2008). Pendidikan formal pada setiap tahunnya melakukan proses penerimaan siswa baru. Hasil penerimaan siswa yang baik dan berkualitas, dapat dilihat dalam proses penerimaan menggunakan cara dan alat yang tepat.

Proses seleksi awal diperlukan untuk menjaring peserta didik sesuai dengan minat dari setiap calon peserta didik. Penuturan Sriyana (Wakil Kepala Sekolah Bidang Kurikulum SMKN 2 Depok Sleman), proses seleksi awal terbagi menjadi beberapa tahaptahap penyeleksian, diantaranya tahapan seleksi pengelompokan nilai, tes kesehatan dan postur tubuh, tes buta warna, dan tes minat. Didasarkan pada aturan penerapan kurikulum baru yaitu Kurikulum 2013, pihak SMK wajib dilaksanakan peminatan dalam proses penerimaan peserta didik baru. Setelah seleksi yang baik, perlu dilakukan proses pendidikan yang berkualitas untuk memperoleh lulusan yang berkualitas pula.

Berdasarkan Permendikbud No.70 tahun 2013 tentang Kerangka Dasar dan Struktur Kurikulum SMK-MAK, menyebutkan tujuan dari Kurikulum 2013 adalah mempersiapkan 
manusia Indonesia agar memiliki kemampuan hidup sebagai pribadi dan warga Negara yang beriman, produktif, kreatif, inovatif, dan efektif serta mampu berkontribusi pada kehidupan bermasyarakat, berbangsa, bernegara dan peradaban dunia. Proses pencapaian tujuan pendidikan dengan Kurikulum 2013 memperhatikan semua faktor, mulai dari pendaftaran sampai lulusan lembaga pendidikan.

Pengembangan kompetensi peserta didik dapat dilakukan secara maksimal, jika dapat diidentifikasi dari awal pada saat penerimaan peserta didik. Proses identifikasi dapat dilakukan dengan pemetaan minat, bakat dan motivasi yang terdapat didalam psikologi peserta didik. Pemetaan dapat dilakukan dengan menggunakan wawancara dan tes didalam proses penerimaan siswa baru. Hasil pemetaan awal yang dapat berupa minat bakat siswa, dapat digunakan sebagai referensi tindakan yang akan diambil dalam proses selanjutnya.

Proses pembelajaran dan pendidikan harus dikembangkan yang sesuai dengan kebutuhan pengembangan kompetensi peserta didik. Peserta didik memiliki kesempatan dan hak untuk memperoleh pengembangan kompetensi yang sama berdasarkan minat awal masuk dalam pendidikan kejuruan. Pengembangan kompetensi yang baik dalam sekolah kejuruan apabila sejalan dengan minat dan bakat siswa pada awal pemetaan. Dengan pengembangan kompetensi yang baik, diharapkan dapat menghasilkan lulusan SMK yang berkualitas sehingga mudah terserap di dunia usaha dan industri.

Kesadaran diri tiap peserta didik akan membawa mereka mengetahui dan mengenal tentang potensi diri, bakat, minat dan kepribadian yang mereka miliki. Hal ini dapat memudahkan peserta didik dalam mengembangkan kompetensi sesuai dengan bidang kejuruan dan karir pekerjaan. Oleh karena itu sangatlah penting bagi pengelola pendidikan dan institusi pendidikan, serta masyarakat pada umumnya untuk mengetahui potensi yang dimiliki sejak dini, sehingga siswa atau individu kelak mempunyai perencanaan karier yang berkualitas dan berdedikasi tinggi (Istiqomah, 2010).

Berdasarkan data yang dikutip dari buku Toyota Talent (Jeffry dan David, 2007, p.5), menjelaskan bahwa bakat alami seseorang yang didapat dari lahir berkontribusi sebesar 10 persen (atau kurang) dari total diagram bakat yang dimiliki orang tersebut. Berdasarkan kutipan tersebut, menunjukkan bahwa bakat seseorang dapat ditingkatkan dengan proses pembelajaran dan latihan terus-menerus. Bakat diri yang dapat dikembangkan menjadi kompetensi, akan berkembang dengan baik jika diketahui sejak awal.

Seperti yang dikutip dari Saifuddin Azwar (2004, p.75), menjelaskan bahwa setelah kelahiran, pengaruh faktor lingkungan terhadap individu semakin penting dan besar. Proses yang berpengaruh setelah masa ini adalah proses belajar (learning) yang menyebabkan perbedaan perilaku individu satu dengan yang lainnya. Faktor lingkungan memberikan pengaruh terhadap psikologi peserta didik sangat besar setelah kelahiran. Lingkungan dapat berupa tempat dimana peserta didik tinggal, dan juga tempat dimana peserta didik menempuh pendidikan. Lingkungan memberikan pembelajaran bagi peserta didik, yang mempengaruhi tingkah laku, kepribadian dan kompetensi. Perubahan ini disebabkan karena proses adaptasi dan proses pembelajaran yang terjadi.

Menurut pengamat pendidikan yang menjadi dosen UNP, Ali Zamar, mengatakan perlu adanya tes minat dan bakat saat seleksi masuk SMK. Tujuannya adalah untuk meningkatkan kualitas pendidikan atau mutu setelah tamat. Minat ini akan menentukan keberhasilan peserta didik tersebut dalam jurusan yang mereka ambil (padangekspres. co.id; 4 Juli 2013). Tes semacam ini masih jarang dilakukan oleh pihak SMK guna meningkatkan kualitas kompetensi lulusan sekolah kejuruan.

Dikutip dari Permendikbud No.70, menjelaskan bahwa pemilihan peminatan Bidang Keahlian dan program keahlian dilakukan saat peserta didik mendaftar pada SMK/MAK. Pilihan pendalaman peminatan keahlian dalam bentuk pilihan Paket Keahlian dilakukan pada semester 3, berdasarkan nilai rapor dan/atau rekomendasi guru BK di SMK/MAK dan/atau hasil tes penempatan (placement test) oleh psikolog. 


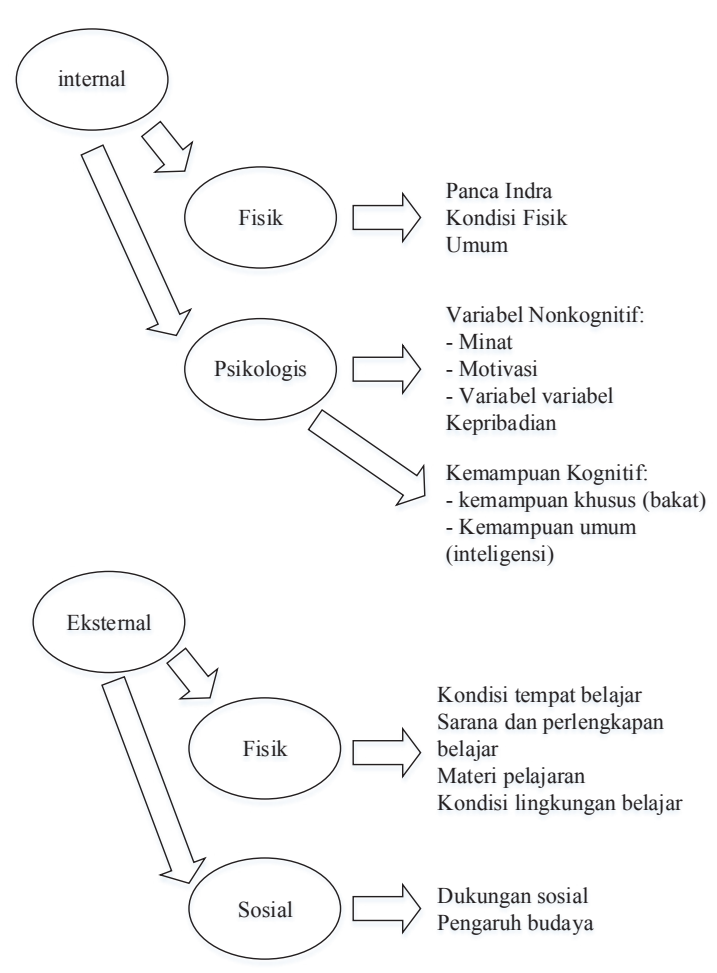

Gambar 1. Faktor-Faktor yang Dapat Mempengaruhi Hasil Belajar (sumber: Azwarz, 2004, p.165)

Proses peminatan dibagi menjadi beberapa bagian. Pemilihan peminatan calon peserta didik terhadap bidang keahlian dan program keahlian dilakukan pada saat proses penerimaa siswa baru. Diharapkan calon peserta didik/ siswa yang nantinya akan diterima memiliki minat tinggi pada program keahlian pilihannya. Setelah proses peneriamaan dan pembelajaran berlangsung selama dua semester, diharapkan mampu meningkatkan minat siswa.

Bagi siswa yang selama dua semester tersebut merasa kurang minat di program keahlian pilihannya, akan diberikan fasilitas untuk peminatan keahlian dalam bentuk pilihan paket keahlian pada semester tiga. Proses peminatan keahlian dilakukan dengan mempertimbangkan beberapa variabel, diantaranya nilai rapor dan atau rekomendasi guru bimbingan konseling. Selain itu proses peminatan program keahlian dengan menggunakan tes penempatan (placement test) yang dilakukan oleh psikolog.

Tujuan dari peminatan itu sendiri dijelaskan dalam pedoman peminatan yang dikeluarkan Kementrian Pendidikan dan
Kebudayaan RI (Mei, 2013) yang dapat dijabarkan bahwa pelayanan peminatan peserta didik merupakan bagian dari upaya advokasi dan fasilitasi perkembangan peserta didik agar secara aktif mengembangkan potensi dirinya untuk memiliki kekuatan spiritual keagamaan, pengendalian diri, kepribadian, kecerdasan, akhlak mulia, serta keterampilan yang diperlukan dirinya, masyarakat, bangsa, dan negara (arahan Pasal 1 angka 1 UU Nomor 20 Tahun 2003 tentang Sistem Pendidikan Nasional) sehingga mencapai perkembangan optimal. Perkembangan optimal bukan sebatas tercapainya prestasi sesuai dengan kapasitas intelektual dan minat yang dimilikinya, melainkan sebagai sebuah kondisi perkembangan yang memungkinkan peserta didik mampu mengambil pilihan dan keputusan secara sehat dan bertanggung jawab serta memiliki daya adaptasi tinggi terhadap dinamika kehidupan yang dihadapinya.

Sedangkan tes bakat (aptitude test) dapat didefinisikan sebagai kemampuan belajar bawaan dalam bidang khusus yang diperlukan untuk memfasilitasi belajar, kecerdikan, kepandaian, kesesuaian, kesiapan, kecenderungan, alam atau diperoleh disposisi atau kapasitas untuk aktivitas tertentu. Penilaian bakat dapat digunakan untuk memprediksi keberhasilan atau menentukan jenjang pendidikan yang sesuai (Sutan, 2012, p.2). Seperti minat, bakat juga dapat dilihat melalui ciri-ciri yang dimiliki seorang peserta didik. Bakat memiliki peranan penting dalam keberhasilan seorang peserta didik pada jurusan atau kompetensi yang dipilihnya. Bakat dapat dikatakan sebagai dasar kompetensi yang perlu untuk dilatih dan dikembangkan sehingga menjadi keahlian yang tepat. Karena sangat pentingnya guna penentuan jurusan atau kompetensi, maka bakat perlu untuk dilihat diawal penerimaan peserta didik. Berikut tingkatan kontribusi keterampilan dalam suatu bidang tes dalam pemetaan tes bakat dalam bidang keteknikan.

Tes bakat banyak dipakai di dalam recruitment tenaga kerja oleh suatu perusahaan, guna melihat kompetensi yang dimiliki oleh calon tenaga kerja. Tes yang digunakan dengan menggunakan model kalkulasi nilai untuk 
Tabel 1. Kompetensi Dasar Siswa Bidang Robotika

\begin{tabular}{|c|c|c|}
\hline Dasar Keahlian & Sub Kompetensi & Indikator \\
\hline Mekanik & $\begin{array}{ll}\text { 1. } & \text { Dasar mekanik } \\
\text { 2. } & \text { Gerakan mekanik } \\
\text { 3. } & \text { Perbandingan gerak } \\
\text { mekanik }\end{array}$ & $\begin{array}{l}\text { 1. Mampu mengidentifikasi jenis mekanik } \\
\text { 2. Mampu mengidentifikasi gerakan suatu } \\
\text { mekanik } \\
\text { 3. Mampu menghitung perbandingan gear dan } \\
\text { pully }\end{array}$ \\
\hline Elektronik & $\begin{array}{l}\text { 1. Dasar elektronik } \\
\text { 2. Dasar kendali } \\
\text { 3. Logika dasar }\end{array}$ & $\begin{array}{l}\text { 1. Mampu mengidentifikasi komponen } \\
\text { elektronik } \\
\text { 2. Mampu menjelaskan kendali elektronik } \\
\text { 3. Mampu menjelaskan fungsi dan kerja dari } \\
\text { gerbang logika dasar }\end{array}$ \\
\hline Komputer & $\begin{array}{l}\text { 1. Pemodelan 3D } \\
\text { 2. Pemrograman }\end{array}$ & $\begin{array}{l}\text { 1. Mampu mengidentifikasi gambar dalam 3D } \\
\text { dari benda geometri atau benda kerja } \\
\text { 2. Mampu melakukan pemograman dasar }\end{array}$ \\
\hline Matematik & $\begin{array}{ll}\text { 1. } & \text { Aritmatik } \\
\text { 2. } & \text { Squensial }\end{array}$ & $\begin{array}{l}\text { 1. Mampu melakukan perhitungan dasar } \\
\text { 2. Mampu melakukan perhitungan berkelanjutan }\end{array}$ \\
\hline
\end{tabular}

melihat tingkatan dan membuat keputusan. Keputusan yang dibuat digunakan untuk memutuskan apakah calon tenaga kerja diterima atau tidak. Hal ini berbeda dengan kondisi penggunaan tes minat dan bakat di dunia pendidikan. Tes minat dan bakat minim sekali digunakan dalam penerimaan peserta didik, atau digunakan untuk mengetahui kemampuan awal dari peserta didik.

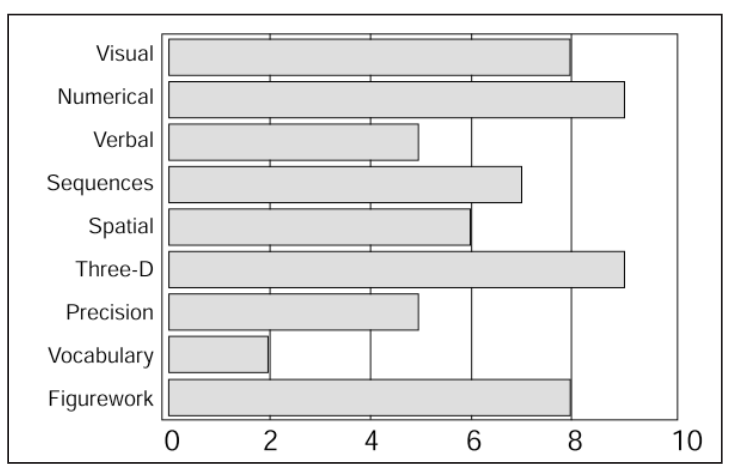

Gambar 2. Pemetaan Bakat Bidang Keteknikan (sumber: Barrnett, 2009, p.115)

Bidang keahlian robotika dipandang sebagai suatu keterampilan yang dapat membekali lulusan SMK masuk dalam dunia industri. Terutama industri sekarang sudah banyak yang menggunakan sistem otomasi atau robotik. Oleh karena itu siswa harus dibekali keterampilan dasar dalam bidang robotika, terutama program keahlian yang terkait dengan robotik.

Dalam buku John J.Craig yang berjudul Introduction to Robotics Mechanics and Control (2005, p.3), dijelaskan bahwa robotika merupakan ilmu tentang mekanik dan kontrol yang mendasari kompetensi dalam bidang robotika, bukan merupakan ilmu baru. Keilmuan dalam robot terdapat beberapa topik klasik yang dikumpulkan sehingga menjadi topik bahasan baru tentang robotika. Beberapa keilmuan dasar seperti Teknik Mesin (mechanical engineering), Matematika (mathematic), teori pengendali, Teknik Elektro (electrical engineering), dan Ilmu Komputer (computer science). Robotika saat ini menjadi keterampilan yang banyak diminati siswa disekolah, terutama program keahlian keteknikan, seperti elektro, elektronika, dan mesin.

Teknik Mesin memberikan kontribusi dalam pemahaman suatu mesin yang bergerak dan diam (dinamik dan statis). Matematika memebrikan fungsi untuk dapat menggambarkan secara perhitungan suatu gerakan dari manipulator. Teori kendali memberikan pembelajaran tentang untuk merancang dan mengevaluasi suatu struktur kerja guna mewujudkan suatu gerakan atau aplikasi gaya. 
Teknik listrik memberikan pengetahuan tentang merancang suatu sensor dan antarmuka untuk robot. Ilmu komputer berkontribusi terhadap pemrograman terhadap perangkat kendali sesuai tugas atau gerakan yang diinginkan. Beberapa kompetensi dasar tersebut mendasari kompetensi dalam bidang robotika. Berdasarkan hal tersebut, untuk melihat potensi bidang robotika perlu ditekankan pada empat macam keilmuan dasar yang menyusun kompetensi robotika.

Tes minat dan bakat bukan hanya kalkulasi suatu nilai, tetapi mencerminkan gambaran pola pikir dari peserta didik. Pola yang dibentuk dari bidang keteknikan dengan melihat minat dan bakat harus mampu dideteksi secara dini polanya. Dapat dikatakan bahwa tes minat dan bakat dalam mengambil suatu keputusan sangat rumit. Untuk itu diperlukan suatu metode pemecahan yang tepat untuk mampu melihat dan membedakan pola yang terbentuk.

Dilihat dari segi sudut pandang bidang lain, saat ini sudah banyak diaplikasikan kecerdasan buatan yang mampu mengambil suatu keputusan dengan cepat dan tepat. Sejumlah variabel masukan yang rumit dan komplek dapat terselesaikan dengan baik adanya penggunaan kecerdasan buatan. Beberapa jenis tes telah dikembangkan mengacu pada kemajuan teknologi dan cara pemecahan masalah. Pengembangan mulai dari media yang digunakan, sampai dengan bagaimana cara pengambilan kesimpulan atau keputusan dari hasil tes. Tetapi penerapan kecerdasan buatan terutama penggunaan jaringan syaraf tiruan pada pengembangan tes, belum pernah diterapkan dalam pengambilan keputusan.

Banyak metode pemecahan masalah perhitungan dalam pemrogram komputer. Salah satunya menggunakan sistem cerdas yaitu jaringan syaraf tiruan. Kecerdasan buatan adalah salah satu bidang ilmu komputer yang mendayagunakan komputer sehingga dapat berperilaku cerdas seperti manuasia (Hartati dan Sari, 2013, p.1). Aktifitas manusia yang ditirukan oleh sistem cerdas meliputi penalaran, penglihatan, pembelajaran, pemecahan masalah, pemahaman bahasa alami dan lainnya. Beberapa bidang yang masuk dalam kecerdasan buatan yaitu seperti Robotika (Robotics), Penglihatan Komputer (Computer
Vision), Pengolahan Bahasa Alami (Natural Language Processing), Pengenalan Pola (Patern Recorgnition), Sistem Syaraf Tiruan (Artificial Neural System), Pengenalan Suara (Speech Recognition), Sistem Pakar (Expert System). Kecerdasan buatan menyelesaikan permasalahan dengan mendayagunakan komputer untuk memecahkan masalah yang komplek dengan cara mengikuti proses penalaran manusia.

Jaringan syaraf digunakan untuk memecahkan masalah dengan formulasi yang kompleks atau tidak diketahui, yaitu terdapat model kausal atau perhitungan matematis, serta biasanya masalah yang akan dipecahkan tidak sepenuhnya dipahami. Jaringan saraf menggunakan data yang tersedia untuk mendapatkan pola yang relevan dalam membedakan kelompok. Kemampuan inilah yang dinamakan sebagai kecerdasan buatan karena menyerupai jaringan syaraf manusia. Struktur neuron jaringan syaraf dalam pemrosesan data dapat digambarkan sebagai berikut:

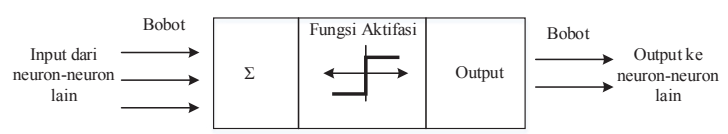

Gambar 3. Struktur Neuron Jaringan Syaraf

(Kusumadewi, 2003, p.210)

Jaringan syaraf tiruan (JST) memiliki beberapa metode pembelajaran untuk menentukan nilai bobot dari masig-masing masukan. Salah satu metode pembelajaran adalah perceptron. Perceptron biasanya digunakan untuk mengklasifikasikan suatu tipe pola tertentu yang sering dikenal dengan pemisahan secara linier (Kusumadewi, 2003, p.224). Algoritma yang digunakan oleh aturan perceptron ini akan mengatur parameter-parameter bebasnya melalui proses pembelajaran. Berikut model pembelajaran JST perceptron dengan fungsi aktifasi bipolar hard limit.

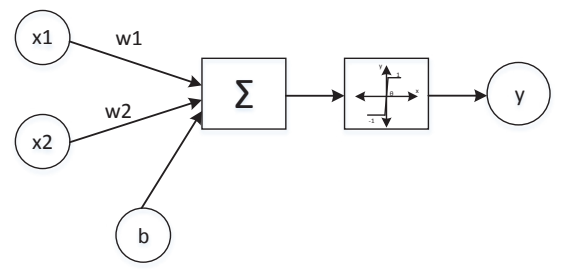

Gambar 4. Model Jaringan Perceptron 
Model JST perceptron diatas merupakan jenis single layer, yang terdiri dari lapisan masukan yang kemudian hasilnya diproses untuk layer keluaran secara langsung. Algoritma dari model perceptron diatas dapat dijabarkan sebagai berikut (Kusumadewi, 2003:224):

1) Inisialisasi semua bobot dan bias

Bobot dan bias $(b)=0$, dan learning rate $(\alpha)$ lebih besar dari nol dan lebih kecil dari 1.

2) Selama kondisi berhenti bernilai false, lakukan langkah-langkah sebagai berikut: Untuk setiap pasangan pembelajaran s-t, kerjakan:

Set input dengan nilai sama dengan vector input:

$$
\mathrm{x}_{1}-\mathrm{s}_{1}
$$

Nilai masukan pada jaringan input $\left(\mathrm{x}_{1}\right)$ merupakan nilai yang sama dengan input dari luar jaringan $\left(\mathrm{s}_{1}\right)$.

Hitung respon untuk unit output:

$$
\begin{aligned}
& y_{\text {in }}=b+\sum_{i} \mathrm{x}_{\mathrm{i}} \mathrm{w}_{\mathrm{i}} \\
& \mathrm{y}=\left\{\begin{array}{lr}
1, & \text { jika } \mathrm{y}_{-} \text {in }>\theta \\
0, & \text { jika }-\theta \leq \mathrm{y}_{-} \text {in } \theta \\
-1, & \text { jika } \mathrm{y}_{\text {in }}<-\theta
\end{array}\right.
\end{aligned}
$$

$\mathrm{y}_{\text {in }}$ merupakan jumlah dari bias masukan ditambah jumlah dari bobot dikali nilai masukan masing-masing, selanjutnya dikenakan fungsi aktifasi dengan batas threshold $(\theta)$. Nilai keluaran (y) dari aktifasi adalah bipolar, yang terdiri dari 1, 0 dan -1 dengan syarat masing-masing seperti pada rumus diatas.

Perbaiki bobot dan bias jika terjadi error: Jika $\mathrm{y} \neq \mathrm{t}$ maka:

$$
\begin{gathered}
\mathrm{w}_{\mathrm{i}}(\text { baru })-\mathrm{w}_{\mathrm{i}}(\text { lama })+\mathrm{atx}_{\mathrm{i}} \\
\mathrm{b}(\text { baru })-\mathrm{b}(\text { lama })+\mathrm{at}
\end{gathered}
$$

Jika tidak, maka:

$$
\begin{gathered}
\mathrm{w}_{\mathrm{w}}(\text { baru })-\mathrm{w}_{\mathrm{i}}(\text { lama }) \\
\mathrm{b}(\text { baru })-\mathrm{b} \text { (lama })
\end{gathered}
$$

3. Masuk dalam fase terakhir dalam satu perulangan, yaitu apabila aktifasi keluaran (y) tidak sesuai dengan target (t) yang telah ditentukan maka, bobot (w) baru sama dengan jumlah antara bobot lama dengan perubahan bobot $\left(\mathrm{atx}_{1}\right)$. Sedangkan apabila keluaran aktifasi sama dengan target, maka nilai bobot baru sama dengan nilai bobot sebelumnya, dengan kata lain tidak ada perubahan bobot.

4. Tes kondisi berhenti: jika tidak terjadi perubahan bobot maka kondisi berhenti true, namun jika masih terjadi perubahan bobot maka kondisi berhenti false.

Penelitian pengembangan perlu dilakukan untuk memperoleh suatu perangkat lunak yang berfungsi sebagai perangkat tes minat dan bakat berfokus pada kompetensi bidang robotika. Penggunaan JST sebagai pembelajaran dan pengenalan pola pada hasil tes minat dan bakat yang diinginkan. Diharapkan hasil yang diperoleh dari perangkat lunak yang dibangun dapat mengenali pola minat dan bakat responden tes, dan pengambilan keputusan dengan cepat serta tepat.

\section{METODE PENELITIAN}

Metode penelitian yang digunakan adalah metode penelitian dan pengembangan atau Research and Development (R\&D). Pendekatan yang pertama untuk pengembangan perangkat lunak menggunakan model water fall dalam Pressman (2010, p.39). Pendekatan model kedua menggunakaan pendekatan penelitian dalam bidang pendidikan untuk memperoleh penguatan hasil penelitian terkait bidang pendidikan yang dilakukan. Pendekatan model yang digunakan adalah penelitian pengembangan pendidikan $(\mathrm{R} \& \mathrm{D})$ model Dick dan Carey yang tersusun dalam 10 langkah penelitian sebagai berikut: (1) assess needs to identify goals; (2) conduct instruction analysis; (3) Analyze learners and contexts; (4) write performance objective; (5) develop assessment instruments; (6) develop instructional strategy; (7) develop and select instructional materials; (8) design and conduct formative evaluation of instruction; (9) instruction, (10) design and conduct summative evaluation dalam Borg and Gall (2003, p.571).

Model pengembangan perangkat lunak tes minat dan bakat dapat diuraikan menjadi 
Tabel 2. Pengembangan Soal Minat dan Bakat

\begin{tabular}{llc}
\hline Jenis & Indikator & Jumlah soal \\
\hline \multirow{3}{*}{ Minat } & Bidang Mekanik & 3 \\
& Bidang Elektronik & 5 \\
& Bidang Pemrograman/komputer & 4 \\
& Bidang Matematika/Perhitungan & 3 \\
& Kemampuan Dalam Perhitungan & 5 \\
\multirow{3}{*}{ Bakat } & Kemampuan dalam Pemahaman Bahasa atau Perintah & 6 \\
& Kemampuan dalam Memahami Gambar 2D/3D & 11 \\
& Kemampuan dalam Bidang Keteknikan Robotika (Elektronik, & 8 \\
\hline Jumlah & Mekanik, Komputer) & 45 \\
\hline
\end{tabular}

beberapa langkah, yaitu; (1) Identifikasi kebutuhan; (2) Pengembangan produk awal; (3) Evaluasi dan pengujian internal; (4) Penyempurnaan produk tahap pertama; (5) Ujicoba sekala terbatas; (6) Analisis dan penyempurnaan produk tahap kedua; (7) Ujicoba skala luas; dan (8) Finalisasi produk. Prosedur pengembangan dibagi menjadi tiga tahapan yaitu; (1) pengembangan antarmuka; (2) pengembangan jaringan syaraf tiruan; dan (3) pengembangan bank soal tes minat dan bakat. Evaluasi pengembangan perangkat lunak dilakukan dengan dua model yaitu secara internal dengan melakukan pengujian pada saat pemrograman dari setiap kode program, fungsi dan kerja secara menyeluruh sistem yang dikembangkan. Sedangkan secara eksternal dengan pengujian kepada sekolah (first user) dan panitia penerimaan siswa baru (end user). Subjek uji coba dibagi menjadi dua, uji coba secara terbatas pada 10 siswa dan uji coba secara luas sebanyak 31 siswa.

Data penelitian diambil menggunakan observasi, angket, dan wawancara. Teknik analisis data menggunakan statistik diskriptif untuk menjelaskan hasil penelitian pengembangan perangkat lunak.

\section{HASIL DAN PEMBAHASAN}

\section{Hasil pengembangan}

Hasil Pengembangan antarmuka perangkat lunak yang dibangun menggunakan macromedia flash dapat dilihat seprti gambar berikut ini.

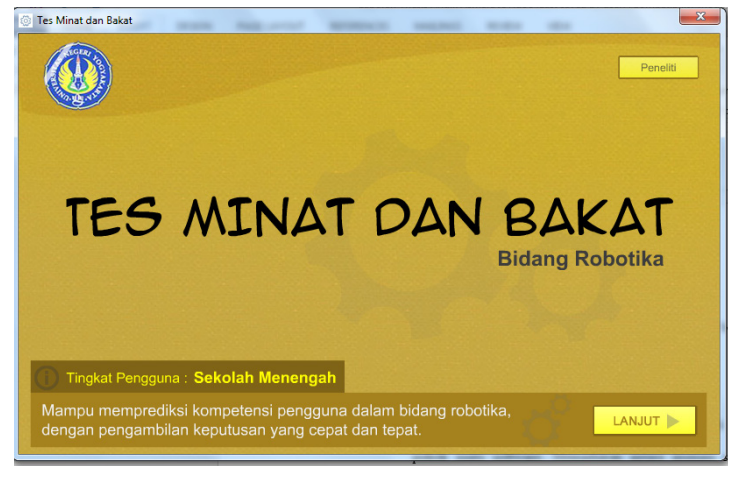

Gambar 5. Tampilan Awal Produk

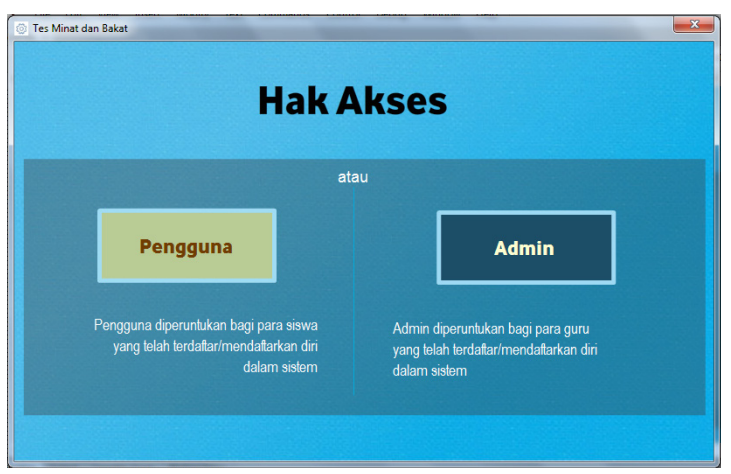

Gambar 6. Tampilan Pilihan Hak Akses

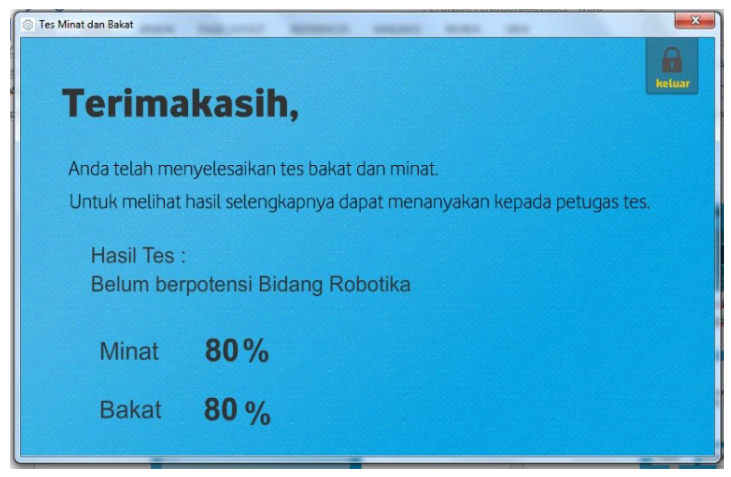

Gambar 7. Tampilan Kesimpulan Hasil Tes 
Pengembangan juga dilakukan pada soal tes minat dan bakat pada bidang robotika yang dapat diperinci pada tabel-2. Soal minat dan bakat dibuat dalam format JPEG tiap masingmasing soal dan pilihan jawabannya. Soal dan jawaban tersebut akan disimpan pada suatu folder data based soal, kemudian diambil dan ditampilkan dalam perangkat lunak yang dibangun. Untuk meningkatkan kualitas hasil tes, maka penempatan pilihan jawaban akan diacak, sehingga pengguna satu dengan yang lain berbeda penempatan pilihan jawabannya (Tabel 1).

Pengembangan model sistem JST dilakukan guna membantu dalam membangun program perangkat lunak tes minat dan bakat. Berikut model JST yang dikembangkan.

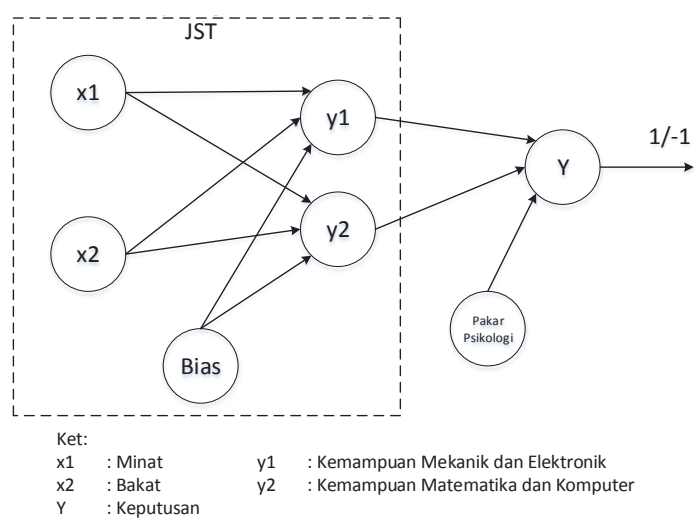

Gambar 8. Sistem JST Tes Minat dan Bakat Bidang Robotika

Jaringan syaraf tiruan yang dibangun menggunakan model perceptron single layer. Model aktifasi yang digunakan dengan bipolar (1 dan -1) untuk membedakan dua keluaran berpotensi atau tidak berpotensi. Pilihan jawaban tes sebagai masukan jaringan, dan keputusan berpotensi atau tidak dalam bidang robotika sebagai keluarannya.

Pengembangan pola target pembelajaran jaringan syaraf tiruan dilakukan dengan mengacu pada ahli psikologi pendidikan. Sepuluh target pola digunakan dalam proses pembelajaran jaringan syaraf tiruan untuk memperoleh bobot pada masukan dan bias baru. Berikut kesepuluh pola yang dikembangkan.

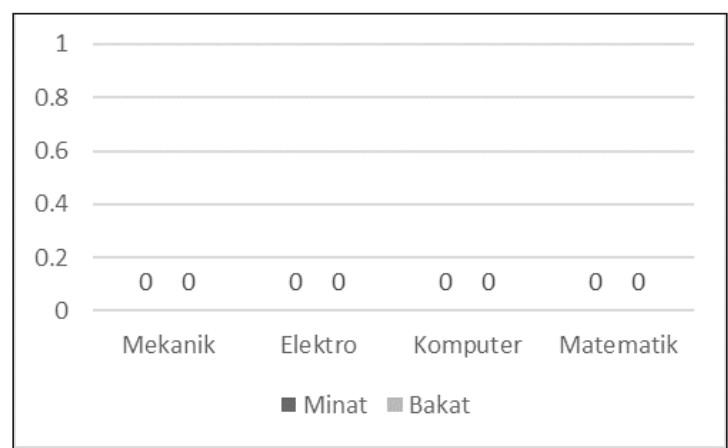

Gambar 9. Pola-1 dengan Target -1

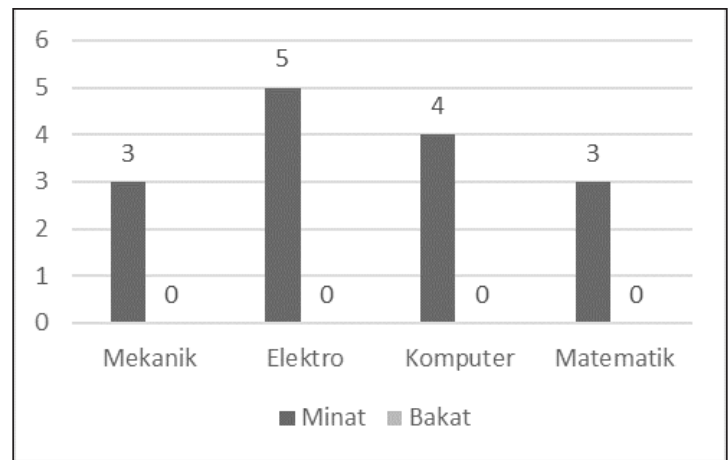

Gambar 10. Pola-2 dengan Target -1

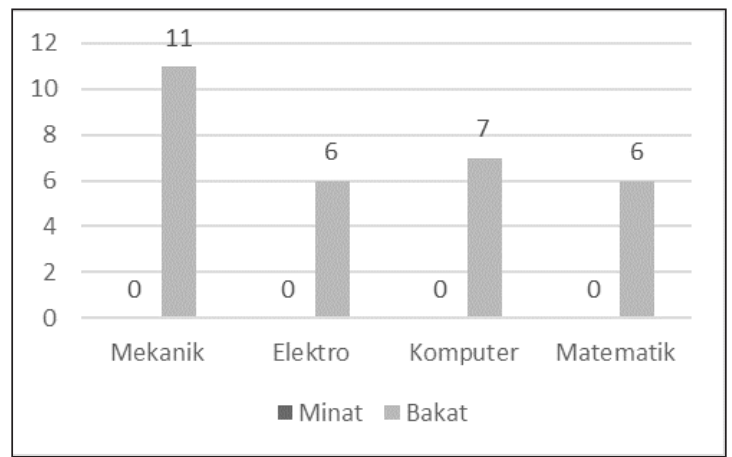

Gambar 11. Pola-3 dengan Taget 1

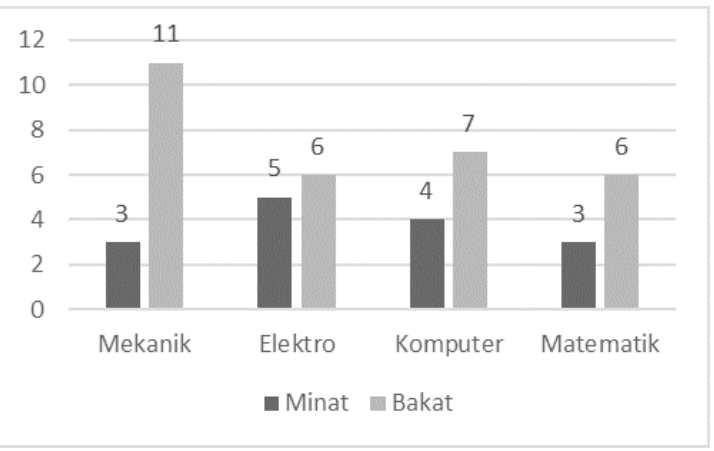

Gambar 12. Pola-4 dengan Target 1 


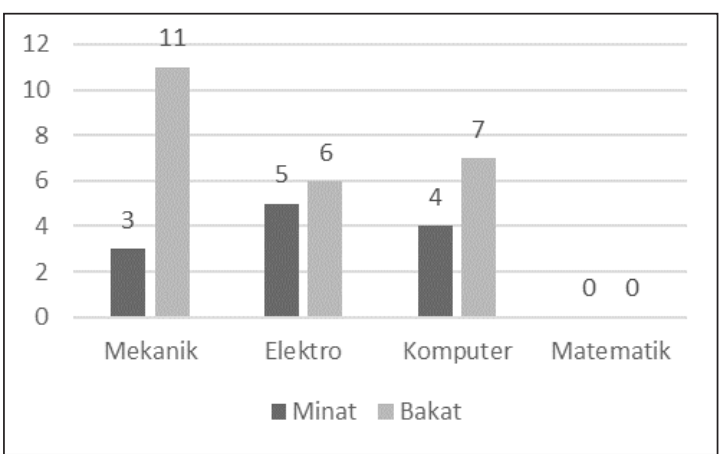

Gambar 13. Pola-5 dengan Target 1

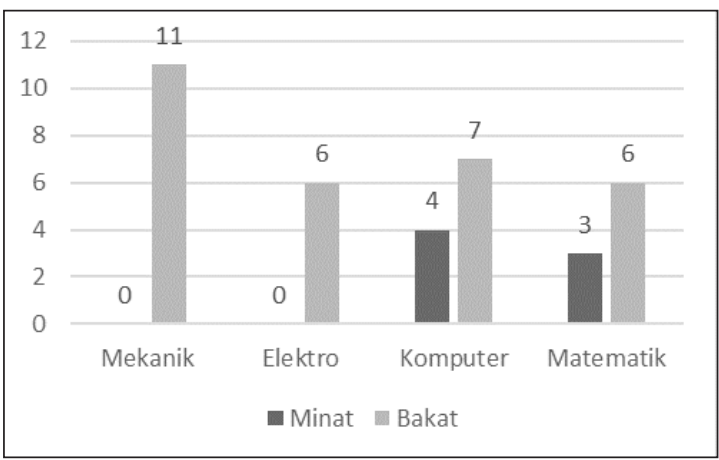

Gambar 14. Pola-6 dengan Target 1

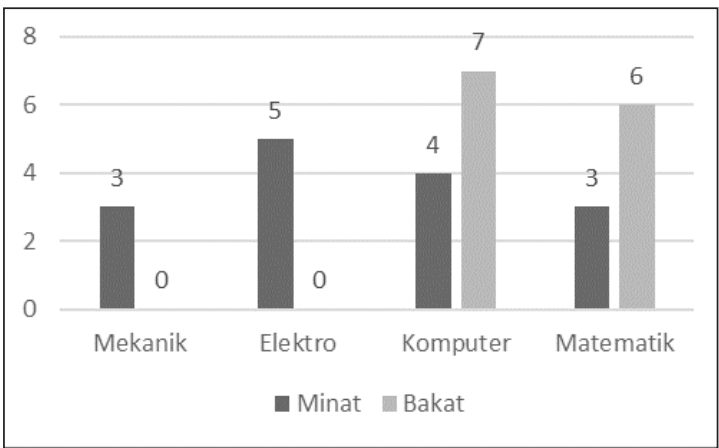

Gambar 15. Pola-7 dengan Target -1

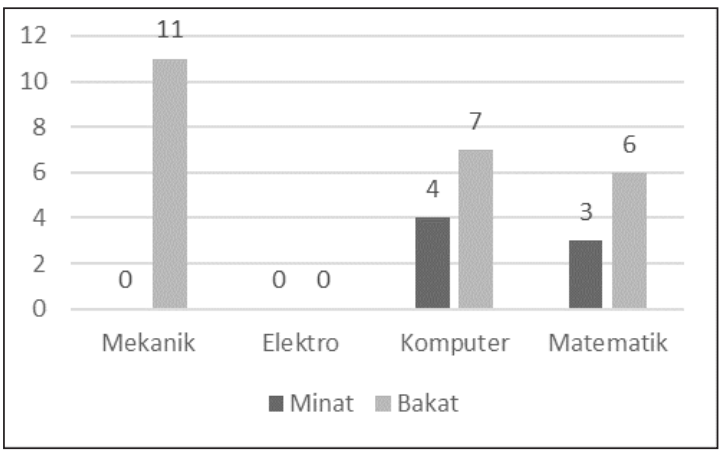

Gambar 16. Pola-8 dengan Target -1

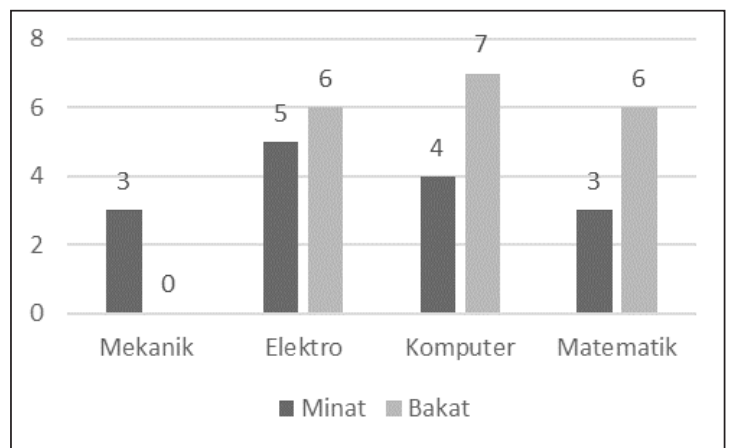

Gambar 17. Pola-9 dengan Target 1

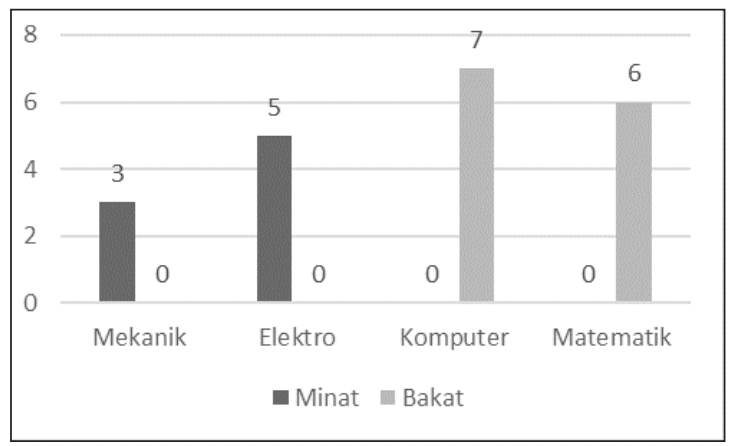

Gambar 18. Pola-10 dengan Target 1

Pengembangan dilakukan sampai pada tahap pembuatan standart operasional procedure (sop). Pengembangan ini bertujuan untuk memberikan suatu petunjuk penggunaan perangkat lunak yang baik dan benar. Peggunaan yang baik dan benar menentuka hasil akhir dari suatu tes berbantuan komputer.

\section{Hasil pengujian}

Hasil pengujian dibagi menjadi 3 bagian besar yaitu:

\section{Pengujian perangkat lunak}

Pengujian perangkat lunak menggunakan motode white box testing, dengan dilakukan dengan pengujian setiap unit atau fungsi program. Selanjutnya untuk melihat sistem yang sudah jadi satu kesatuan menggunakan black box testing, dengan menjalankan program melihat kerja, kinerja secara menyeluruh melibatkan pengguna dan beberapa ahli dalam bidang psikologi pendidikan, pengukuran pendidikan, JST, dan robotika. Pengujian menunjukan bahwa perangkat lunak yang dikembangkan telah sesuai dengan identifikasi 
Tabel 3. Hasil Kesimpulan Tes dalam Pengujian Secara Terbatas

\begin{tabular}{lccl}
\hline Nama & Minat & Bakat & Keputusan Hasil Tes \\
\hline Siswa-1 & $75 \%$ & $87 \%$ & Memiliki Potensi Bidang Robotika \\
Siswa-2 & $60 \%$ & $77 \%$ & Memiliki Potensi Bidang Robotika \\
Siswa-3 & $66 \%$ & $70 \%$ & Memiliki Potensi Bidang Robotika \\
Siswa-4 & $86 \%$ & $66 \%$ & Tidak Memiliki Potensi Bidang Robotika \\
Siswa-5 & $73 \%$ & $66 \%$ & Tidak Memiliki Potensi Bidang Robotika \\
Siswa-6 & $73 \%$ & $73 \%$ & Memiliki Potensi Bidang Robotika \\
Siswa-7 & $46 \%$ & $56 \%$ & Tidak Memiliki Potensi Bidang Robotika \\
Siswa-8 & $66 \%$ & $66 \%$ & Tidak Memiliki Potensi Bidang Robotika \\
Siswa-9 & $60 \%$ & $76 \%$ & Memiliki Potensi Bidang Robotika \\
Siswa-10 & $60 \%$ & $93 \%$ & Memiliki Potensi Bidang Robotika \\
\hline
\end{tabular}

kebutuhan. Pengujian melibatkan pengguna untuk melihat respon dari hasil produk perangkat lunak yang dikembangkan.

\section{Ujicoba produk dari ahli}

Melibatkan 4 orang ahli dalam bidang psikologi pendidikan, pengukuran pendidikan, jaringan syaraf tiruan dan robotika. Hasilnya mendapatkan kesimpulan bahwa pengembangan produk perangkat lunak telah baik, dapat dilanjutkan pada proses selanjutnya. Walaupun demikian terdapat beberapa saran perbaikan yaitu: (a) Perlu ditambahakan data pelatihan sehingga hasil pembelajaran menjadi lebih akurat; (b) Perlu dilakukan proses pengujian dengan data yang lebih banyak terkait performansi model; (c) Interface perlu diperbaiki agar lebih "manusiawi".

\section{Ujicoba terbatas}

Ujicoba terbatas dilakukan dengan melibatkan 10 siswa yang berminat dalam bidang keahlian robotika pada salah satu lembaga diklat robotik. Hasil pengujian produk untuk mengukur minat dan bakat siswa dengan kesimpulan kompetensi yang dapat dilihat pada tabel 3.

Pada saat yang bersamaan juga dilihat respon pengguna terhadap unjuk kerja produk dari aspek petunjuk penggunaan, tampilan, intro, kesimpulan tes, kemudahan penggunaan, dan kinerja secara menyeluruh. Hasilnya memperoleh nilai rata-rata sebesar 3.03 dari nilai maksimal 4.

\section{Revisi Produk}

Tahapan selanjutnya setelah mendapatkan hasil pengujian awal digunakan untuk melakukan perbaikan dan penyempurnaan perangkat lunak yang dikembangkan. Beberapa bagian dari perangkat lunak diperbaiki dengan menambah ataupun mengurangi sesuai dari masukan penilaian sebelumnya. Berikut bagianbagian yang direvisi: (a) Perbaikan antarmuka pola target dengan merubah scrool bar menjadi radio button agar kerja pengguna lebih effektif; (b) Penambahan array penyimpanan pola dari 10 pola menjadi 50 pola; (c) Penambahan fasilitas waktu pengerjaan soal; (d) Perubahan penempatan pilihan jawaban secara acak.

\section{Kajian produk akhir}

Kinerja perangkat lunak yang dikembangkan perlu dilihat dengan pengujian secara luas. Pengujian tahapan selanjutnya dilakukan pada Sekolah Menengah Kejuruan yang telah menerapkan kurikulum 2013 dan melaksanakan proses peminatan. Sebanyak 31 siswa dilibatkan dalam pengukuran minat dan bakat dalam bidang robotika.

Penerapan jaringan syaraf tiruan pada soal tes minat dan bakat mampu membedakan dua pola target yang telah ditentukan. Bobot yang diperoleh dari proses pembelajaran jaringan syaraf tiruan digunakan untuk menentukan fungsi aktifasi setiap pola jawaban yang terbentuk. Bobot dari 10 pola target pembelajaran mampu digunakan untuk menentukan keputusan akhir dari tes. Hasil 


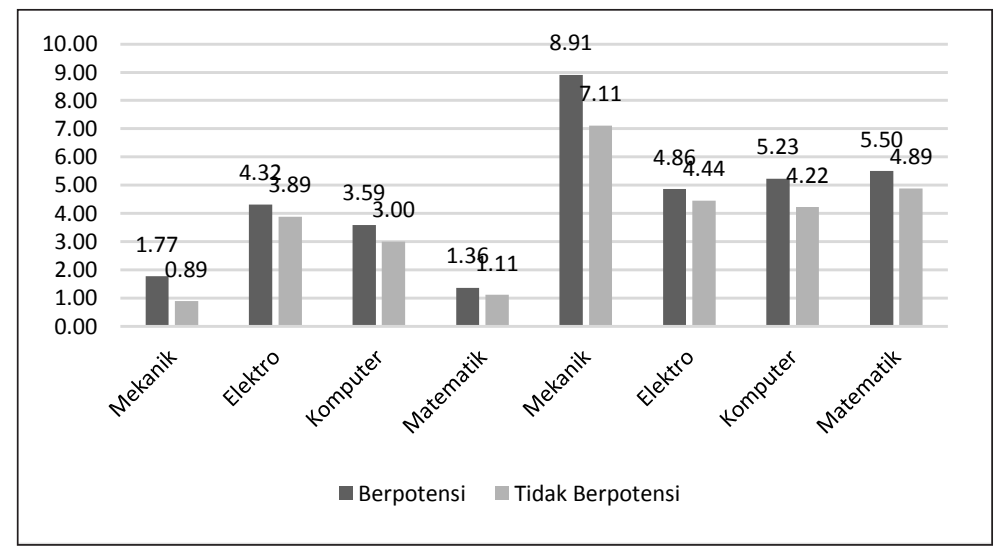

Gambar 19. Rata-Rata Hasil Pengukuran Minat dan Bakat Siswa SMK

penggunaan secara lebih luas terhadap 31 siswa menunjukkan prediksi 22 siswa memiliki potensi bidang robotika dilihat dari minat dan bakat rata-rata yang terdiri minat bidang mekanik sebesar 1.77, minat bidang elektro sebesar 4.32, minat bidang komputer 3.59, dan minat bidang matematik 1.36. Sedangkan siswa yang berpotensi memiliki rata-rata bakat bidang mekanik sebesar 8.91 , bakat bidang elektro sebesar 4.86, bakat bidang komputer 5.23 dan bakat bidang matematik sebasar 5.50.

Prosedur pembuktian lebih luas dilakukan untuk menyakinkan jaringan yang dibangun mampu membedakan kelompok pola masukan yang lebih banyak. Dengan perbandingan 10:31 atau 1:3 sudah termasuk dalam syarat pengujian jaringan syaraf yang baik. 1 merupakan proses pembelajaran dan 3 merupakan proses pengujian pada sample uji. Semple uji guna melihat kemampuan prediksi sitem jaringan, menggunakan 31 siswa SMK yang terkait dengan bidang robotika. Hasil yang diperoleh menunjukan dengan pembelajaran 10 pola target, dapat membedakan 31 pola pengujian dengan tepat berdasar pada bobot yang diperoleh dari jaringan syaraf yang dibangun.

Jaringan syaraf guna menentukan keputusan hasil tes pada pengembangan produk dalam penelitian ini masih bersifat prediktif. Perlu dilakukan pemantauan atau pengamatan berkelanjutan terhadap siswa yang telah diindentifikasi. Proses pengamatan dapat dilakukan selama 1 sampai 2 tahun kedepan sampai akhir dari masa studi siswa. Sehingga dapat diketahui hasilnya, melalui kemapuan, kompetensi dan nilai mata pelajaran yang terkait dengan bidang robotika.

\section{Keterbatasan Penelitian}

(1) Proses pengembangan hanya terbatas pada tahap implementasi, belum sampai pada tahap monitoring. Terkait dengan produk yang dikembangkan masih bersifat prediksi. (2) Implementasi peminatan pada Kurikulum 2013 pada sekolah di Yogyakarta masih sedikit. (3) Pengembangan soal tes dengan jaringan syaraf tiruan masih sebatas jenis supervise (terawasi/ terbimbing).

\section{SIMPULAN DAN SARAN}

\section{Simpulan}

Hasil yang diperoleh dari penelitian ini dapat disimpulkan sebagai berikut; Pertama, jaringan syaraf tiruan dibangun dengan model satu lapisan (single layer), yaitu jawaban soal sebagai masukan dan hasil kesimpulan tes sebagai keluaran sistem. Model yang digunakan dalam proses pembelajaran jaringan syaraf tiruan menggunakan metode perceptron yang memiliki model aktifasi bipolar yang sudah dapat menyimpulkan dua keputusan keluaran, yaitu berpotensi dalam bidang robotika (nilai 1) dan tidak berpotensi dalam bidang robotika (nilai -1). Model pengembangan bank soal (data base soal) merupakan penjabaran keahlian dasar dalam bidang robotika, meliputi ilmu keteknikan dasar mekanik, elektronik, komputer, matematik, yang terdiri dari 15 soal minat dan 30 soal bakat. 
Kedua, hasil penilaian antarmuka dalam ujicoba secara terbatas memperoleh skor 3.03 dari nilai maksimum 4. Hasil validasi ahli juga menunjukkan antarmuka layak digunakan sebagai jembatan komunikasi antara pengguna dan komputer. Hasil pengujian secara inter-nal terahadap infrastruktur jaringan syaraf yang telah dilakukan menunjukan kerja yang baik. Dapat menerima masukan berupa hasil jawaban tes dari pengguna dan mampu menyimpulakan keputusan hasil tes yang telah dilakukan. Diperkuat dengan hasil yang didapat dari validasi ahli dalam bidang kecerdasan buatan, menunjukan bahwa struktur jaringan yang dibangun telah tepat dan layak untuk digunakan. Pembelajaran jaringan syaraf tiruan dilakukan secara terbimbing dengan 10 pola target yang dikembangkan, hasilnya memperoleh nilai bobot yang mampu membedakan ke-10 pola tersebut dengan tepat. Pembuktian secara terbalik juga dilakukan untuk melihat kebenaran hasil pembelajaran terhadap kemampuan untuk membedakan pola target.

Ketiga, produk yang dibangun mampu memprediksi potensi siswa dalam bidang robotika, dengan membedakan 31 pola hasil tes siswa yang berbeda dengan menggunakan bobot yang didapat dari 10 pola pembelajaran. Masih perlu dilakukan pengamatan berkelanjutan terhadap siswa yang bersangkutan untuk melihat ketepatan produk dalam memprediksi. Hasil kesimpulan dari 5 ahli sebagai validator dan penguji secara terbatas menunjukan produk layak untuk digunakan. Diperkuat dengan nilai yang diperoleh dari responden tentang kerja produk secara keseluruhan memperoleh nilai 3.03 dari nilai maksimal 4 .

\section{Saran}

(1) Penelitian ini dapat digunakan dalam proses prediksi minat dan bakat siswa kejuruan. (2) Dapat juga digunakan untuk rekomendasi peminatan program keahlian sesuai dengan minat dan bakat siswa. (3) Dapat digunakan untuk jenis tes prediksi lain, dengan terlebih dahulu dikembangkan instrumen tes (bank soal) dan pola target pembelajaran. (4) Perlu dilakukan pengamatan lebih lanjut 1-2 tahun kedepan terhadap responden yang terukur, guna melihat efektifitas prediksi yang telah dilakukan.

\section{DAFTAR PUSTAKA}

Anonim, SMK perlu tes minat dan bakat. Diakses tanggal 6 Juli 2013: dari http:// padangekspres.co.id.

Azwar, Saifuddin. (2004). Pengantar psikologi inteligensi. Yogyakarta: Pustaka Pelajar

Barrnett, Jim. (2009). Aptitude, personality and motivation tests. London: Kogan Page

Borg, WR. \& Gall MD. (2003). Education research and introduction. New York: Longman Inc.

Depdiknas. (2007). Undang-undang republik Indonesia nomor 20 tahun 2003. Diakses tanggal 29 Juli 2013: dari www. inherent-dikti.net/files/sisdiknas.pdf

Hartati S. dan Sari I. (2013). Sistem pakar dan pengembangannya. Yogyakarta: Graha Ilmu

Istiqomah E., (2010). Minat dan bakat. Diakses 6 September 2013: dari http:// pmc-psychology.blogspot.com/2010/09/ bakat-dan-minat.html

Jeffry K.L and David P.M, (2007). Toyota talent, Edisi Terjemahan, Erlangga; Jakarta

John J.Craig. (2005). Introduction to robotics mechanics and control. USA: Pearson Education Inc. Prentice Hall

Kusumadewi, Sri. (2010). Artificial intelegent. Yogyakarta: Andi Publiser

Mendikbud, (2013). Kerangka dasar dan struktur kurikulum smk-mak. Permendikbud No.70: Kemendikbud

Parker, Erlin L., (2008). Factors that contribute to a successful secondary vocational education program in the state of Mississippi. The University of Southern Mississippi: Proquest Journal

Rosari, Maria. Lulusan SMK 4 juta per tahun mulai 2020. Diakses pada tanggal 30 Aguatus 2014 dari http://www. antaranews.com/berita/384449/lulusansmk-4-juta-per-tahun-mulai-2020 
Pressman, Roger S. (2010). Software engineering a practitioner's approach sevent edition. USA: McGraw-Hill

Runiasari K., (2013). Lulusan smk dominasi pengangguran. Diakses 12 November 2013: dari http://www. suaramerdeka.com/v1/ index.php/read/ news/2013/11/06/178559/LulusanSMK-Dominasi-Pengangguran.

Samani, Muchlas. (1998). Pendidikan kejuruan menyonsong milenium III. Universitas Negeri Surabaya
Suryani B., (2012). Ribuan penganggur kebayakan smk. Diakses 12 November 2013: dari http://www.harianjogja.com/ baca/2012/10/08/disnaker-diy-ribuanpenganggur-kebanyakan-lulusansmk-337012.

Sutan S, dan Hariwijaya M., (2012). Tes bakat dan kepribadian. Yogyakarta: PT. Citra Aji Parama. 